УДК 349.2 (477): 061

DOI https://doi.org/10.32837/apdp.v0i88.3072

Л. П. Шумна, А. М. Сікун, Д. В. Кисельов

\title{
ІНСТИТУТ МЕДІАЦІЇ ЯК АЛЬТЕРНАТИВНИЙ СПОСІБ ВИРІШЕННЯ ТРУДОВОГО СПОРУ
}

Постановка проблеми. Представники будь-якого суспільства достатньою мірою мають досвід участі в конфліктних ситуаціях чи спорах. Як показує життєва практика, на території України існує тенденція, коли громадяни звертаються до суду вже тоді, коли склалась безвихідна ситуація. Латентність породжують такі процеси, як невирішеність спору, відсутність відновлення чи захисту своїх прав, звернення до компетентних органів, які врегульовують спір, чи правосуддя. На відміну від нашої держави, є приклади, коли в інших країнах здебільшого справи доходять до суду або ж вирішуються іншими дієвими альтернативними методами.

Метою проведеного дослідження $є$ аналіз альтернативного методу вирішення трудових спорів - медіацій. Дослідження його дії та перспектив розвитку в сучасних реаліях нашого трудового законодавства в контексті вирішень трудових спорів (конфлікти) між працівником та роботодавцем.

Аналіз останніх досліджень. Останнім часом дослідження та вивчення інституту медіації набирають обертів в нашій державі. Хоча процедура медіації є новою для України й офіційно на рівні законів ще не врегульована, але праці науковців показують, що дослідження медіації привертає особливу увагу (Т.О. Подковенко, О.О. Кармаза, О.Г. Середа й інші).

Виклад основного матеріалу. Якщо узагальнити практику вирішення спорів у нашій країні, можна з упевненістю сказати, що врегулювання спорів відбувається в судовому порядку або із залученням інших компетентних органів. Саме тому натепер у сучасних умовах демократизації та гуманізації нашого суспільства виникає гостра проблема пошуку ефективного і якісного методу врегулювання непорозумінь між роботодавцем та працівниками, знаходження альтернативного шляху вирішення конфліктів у разі виникнення трудових спорів.

Натепер у нашій країні більшість спорів, які стосуються трудової сфери, вирішуються в судовому порядку. Як ми зазначали вище, громадяни України ще не мають такого рівня правової культури, як в європейських країнах, тому до суду звертаються у крайньому разі. Саме тому ми вважаємо позитивним моментом імплементувати досвід правових країн, у яких вже існує та діє інституція медіації.

Зміст терміна «медіація» (від лат. mediatio - «посередництво») розкрито в нормативно-правових актах іноземних держав, а також у наукових працях вітчизняних і закордонних учених.

Як зазначає Т.О. Подковенко, медіацію називають програмою примирення. Це метод, за якого сторони управляють і володіють як самим процесом, так і його результатом - згодою, нічого не вирішується без згоди, взаємопорозуміння сторін $[1$, c. 27$]$. 
У ст. 3 Директиви 2008/52/ЄС «Про деякі аспекти медіації у цивільних та комерційних справах» медіація розглядається як структурована процедура, у якій дві або більше сторін намагаються досягти примирення та згоди самостійно, на добровільній основі, для вирішення спору між ними за допомогою посередника [2, ст. 3].

У результаті розгляду міжнародних документів і праць науковців можна сказати, що медіація - це вид посередництва для вирішення спорів поза судом із залученням посередника, який допомагає сторонам конфлікту налагодити процес комунікації, проаналізувати проблему та дійти певного консенсусу.

Медіація в сучасному їі розумінні почала розвиватися у другій половині XX ст. у країнах англосаксонської системи права - США, Австралії, Великій Британії, пізніше вона поступово почала поширюватися і в інших країнах [3, с. 39].

Загалом медіація передбачала вирішення спорів у сімейних стосунках, але пізніше коло спорів та конфліктів, які можна вирішувати за допомогою процедури посередництва, збільшилось.

У більшості країн світу медіація є визнаним і поширеним методом врегулювання суперечок між людьми. Варто зазначити, що медіація активно розвивається в багатьох країнах та вже виправдала себе в таких країнах, як Польща, Німеччина, Франція, Норвегія, Фінляндія, США, Канада.

Так, у США лише 5\% випадків, про які повідомляється в суді, решта вирішуються мирно [4].

Застосування на практиці медіації має такі переваги:

- зменшення затрат часу та фінансів;

- добровільна участь; можливість у будь-який час покинути стіл переговорів;

- процес ставить за мету не протистояння сторін, а їх діалог;

- конфіденційність процесу;

- унеможливлення стигматизації винної сторони з боку суспільства.

Швидкий процес вирішення трудових спорів шляхом медіації не тільки позитивно впливає на соціально-економічну складову частину суб'єктів спорів, a і на морально-психологічну, адже результат досягнення мети не змушує себе чекати довго.

Так, наприклад, досвід Болгарії показав, що спори вирішуються переважно за одну або дві сесії медіації, які тривають від 2 до 4 годин [5].

У Чехії процедура медіації відбувається також у досить короткі строки. За цей час спір повинен бути врегульований, медіатора обирають зі списків, складених Міністерством праці, або ж запрошують представника за взаємною згодою [6, с.16].

Цікавим є досвід країн, де держава усіляко сприяє проведенню медіації шляхом створення баз даних, реєстрів чи списків медіаторів, де зазначені державні й недержавні (приватні, волонтери) медіатори.

Так, наприклад, у Казахстані, відповідно до ст. 14 Закону Республіки Казахстан «Про медіацію», кожна організація медіаторів веде свій Реєстр професійних медіаторів, які здійснюють медіацію на території цієї країни [7, с. 27].

Як зауважив Д.Є. Кривенко, у межах саме національних реалій, а також з огляду на зменшення бюрократизованості, перевагою медіації можна вважати її оптимальність, поєднання найбільш комфортних умов вирішення трудового спору [8, с. 145]. 
Для ефективного здійснення процесу медіації у трудових спорах необхідно дотримуватися майже всіх тих принципів, що й у судочинстві, щоб не дестабілізувати сам процес та досягти кінцевого результату.

A.O. Стратюк визначає, що до ознак медіації трудового спору належать наступні: «законність (медіація трудових спорів може здійснюватися, якщо відповідає правовим принципам та не порушує правових норм); конфіденційність (гарантується укладанням відповідної угоди між сторонами та медіатором, а також відповідним законодавством щодо повноважень посередника); рефлективність (вона розглядається як здатність людини спрямовувати власну активність на себе); професійність (для забезпечення порозуміння між сторонами конфлікту необхідно послідовне та цілеспрямоване застосування спеціальних методів, які можна опанувати лише у процесі навчання та практики)» [9, с. 160].

Можна виділити одну із ключових ознак медіації під час вирішення трудового спору, це «поступка сторін» заради досягнення результату у процесі вирішення спору. У разі врегулювання конфлікту мирним шляхом сторони досягають консенсусу чи компромісу.

О.О. Григор зазначає, що «відмінність між цими поняттями може бути позначена таким способом: консенсус - загальна усвідомлена згода, компроміс - угода на підставі взаємовигідних поступок, або ж, згідно з іншими джерелами, взаємні поступки» $[10$, с.12].

Щодо поняття компромісу можна сказати, що це поступки з певною вигодою однієї сторони для досягнення взаємного результату, тобто одна сторона жертвує своїми інтересами заради іншої або заради когось. У разі компромісу начебто і досягнений мирний результат, але з'являються негативні наслідки, як-от нераціональна втрата інтересів однієї зі сторін. Консенсус характеризується як пожертва інтересами обох сторін заради спільного результату, або спільна домовленість без негативних наслідків для обох сторін.

В обох випадках досягнення компромісу та консенсусу наявне вирішення спору мирним шляхом, але результат, наслідки та характер виконання рішення - різні. Коли розглядаємо ознаку «поступки сторін» під час вирішення трудового спору, необхідно, щоб ця ознака мала консенсусний характер. Консенсусний характер вирішення трудових спорів прямо передбачає взаємні поступки без зловживання інтересами обох сторін, досягнення взаємними силами результату.

Також необхідно зазначити, що до ознаки медіації як альтернативного способу вирішення трудового спору необхідно віднести «рівність сторін», тобто у процедурі медіації всі учасники рівні незалежно від статусу, владних повноважень, як наслідок, у разі досягнення рівності між сторонами, щодо яких здійснюється процедура медіації, отриманий результат буде мати консенсусний характер, а за нерівності сторін, позиціювання керівника чи уповноваженого органу як сильнішої сторони, яка погодилася на медіацію, результат буде очевидним, матиме компромісний характер.

Як показує досвід закордонних країн, для ефективного здійснення процесу медіації не тільки потрібно дотримуватися особливих принципів здійснення процесу посередництва, а також необхідні інституція та сам суб'єкт, уповноважений 
здійснювати процедуру посередництва. Уряди держав створюють установи й інші організації, які уповноважені здійснювати медіацію.

Із досвіду закордонних держав можна зазначити, що в Німеччині активно діє і розвивається Федеральний союз медіації в економіці та сфері праці(Bundesverband Mediation in Wirtschaft und Arbeitswelt), у Фінляндії призначається так званий державний примиритель, а у Великій Британії діє консультативна служба примирення й арбітражу (Asac Codes of Practice), основною функцією якої є сприяння розвитку виробничих відносин і пропозиція на прохання сторін конфлікту щодо сприяння у вирішенні спору [3, с. 39].

Дуже важливим є те, що в іноземних країнах нормативно закріплено процес посередництва у вигляді законів, які врегульовують не тільки сам процес, а зазначають, що процес медіації може бути призначений судом або сторони добровільно можуть звернутись до установи, яка займається посередництвом. Необхідно зазначити, що в нормативно-правових актах іноземних країн також зазначається юридичний захищений державою статус установи, яка уповноважена здійснювати медіацію.

У Франції процедура медіації прописана у трудовому кодексі, регулюється нормами цього кодексу. У Республіці Білорусь чинний Закон «Про медіацію», яким керуються під час вирішення спорів у трудовій сфері та цивільно-господарських справах, але додатково для вирішення спорів вони керуються директивою Ради Європи «Про деякі аспекти медіації в цивільних і комерційних справах» 2008 р., а також Рекомендацією Ради Свропи «Про медіацію в цивільних справах» № $\mathrm{R}$ (2002) 10, які регулюють медіацію трудових спорів в європейських державах та державах - членах Ради Свропи, які офіційно здійснюють медіацію.

Сучасне чинне українське законодавство заклало підгрунтя щодо позасудового вирішення спорів, передбачило можливість укладення мирової угоди в Цивільному процесуальному та Господарському процесуальному кодексах, законах «Про міжнародний комерційний арбітраж», де передбачено примирення в деяких категоріях справ. Крім цього, велике значення мають такі закони України, як «Про третейські суди» та «Про порядок вирішення трудових та колективних спорів (конфліктів)» [1, с. 29].

Незважаючи на те, що в нашій країні немає закону, який би врегулював чіткий алгоритм функціонування вирішення спорів мирним шляхом, зусилля щодо становлення та розвитку медіації докладають юристи-практики, науковці, а також громадські об'єднання, наприклад такі, як: Українська академія медіації, Український центр медіації, Школа медіації Академії адвокатури України тощо.

Цікавим є досвід закордонних країн, де не існує спеціально створених інституцій, які вповноваженні здійснювати примирення, тому там цей процес покладається на суди та має назву «судова медіація». У судочинстві трудового характеру в закордонних країнах, на відміну від укладення мирової угоди, урегулювання спору за участю судді передбачає досягнення між сторонами угоди, заснованої на їхніх інтересах, щодо спору за участю кваліфікованого посередника (судді). Така угода не завжди оформлюється у вигляді мирової угоди, тоді як судовий розгляд може бути закінчений, наприклад, у зв'язку з відмовою позивача від позову. 
Якщо не досягнуто мету медіації, її наслідками може бути звернення до трудового арбітражу та страйк, звернення до Комісії із трудових спорів та національного суду [6, с. 150].

Можна сказати, що Україна вже стоїть на порозі впровадження медіації у практику вирішення юридичних спорів, спираючись на досвід іноземних країн, що стане дієвим механізмом вирішення трудових спорів та сприятиме позитивному іміджу нашої країни на міжнародній арені. Необхідно зазначити, що спроби узаконити медіацію в нашій країні вже були, це відображено в ініціюванні та поданні проєктів законів «Про медіацію» 2015 та 2019 рр., але, на превеликий жаль, вони не були ухвалені.

15 липня 2020 р. Верховна Рада України на своєму засіданні підтримала проєкт закону «Про медіацію». Законопроєкт № 3504 взято за основу 339 голосами. Документ створено з метою закріплення на законодавчому рівні можливості проведення процедури медіації, яка полягатиме в добровільному позасудовому врегулюванні конфлікту (спору) шляхом переговорів між його сторонами, за допомогою медіатора. Проєктом пропонується визначити правові засади та порядок проведення медіації в Україні, які полягають у такому: процедура медіації застосовуватиметься в будь-яких конфліктах (спорах), які виникають, зокрема, із цивільних, сімейних, трудових, господарських, адміністративних правовідносин, а також у кримінальних провадженнях у разі укладення угод про примирення між потерпілим та підозрюваним, обвинуваченим, в інших сферах суспільних відносин [11].

Але відсутність закону, незважаючи на ухвалення чергового законопроєкту, залишає питання законного регулювання посередництва під час примирення та вирішення трудових спорів шляхом медіації відкритим.

Висновки. Для України впровадження медіації для вирішення трудових спорів буде цікавим досвідом, адже медіація у вирішенні спорів передбачає не тільки безпосередні переговори між працівником та роботодавцем, а й участь посередника, який лише регулює процес. Як показує досвід, переговори без участі незалежного представника можуть погіршити ситуацію та загострити спір. Дієвим методом є розроблення й ухвалення закону, який би врегулював питання посередництва під час вирішення конфліктів та трудових спорів, підбору медіаторів, інституції, яка б займалась медіацією. Після ухвалення закону необхідне створення відкритого реєстру медіаторів.

У Кодексі законів про працю доцільно доповнити статтею гл. XV «Індивідуальні трудові спори», у якій прописати можливість примирення або посередництва під час вирішення спору як спрощеної процедури, яка передує створенню комісії із трудових спорів.

Цікавим було б надати повноваження на здійснення медіації у вирішенні як колективних, так і індивідуальних трудових спорів Національній службі посередництва і примирення, або ці повноваження надати судам, але не в рамках судового процесу, а в рамках здійснення процесу посередництва. Створити навчальні центри, які б готували висококваліфікованих медіаторів.

Медіація є альтернативним та більш доступним варіантом вирішення спорів для громадян нашої держави, яка має свій універсальний конструктивний характер для вирішення того чи іншого спору. 


\section{Jimepamypa}

1. Подковенко Т.О. Інститут медіації : зарубіжний досвід та українські перспективи. Актуальні проблеми правознавства. 2016. Вип. 1. С. 26-31.

2. Directive 2008/52/EC of the European Parliament and of the Council of 21 May 2008 on certain aspects of mediation in civil and commercial matters. URL: https://eur-lex.europa.eu/legal-content/EN/ TXT/?uri=CELEX\% 3A32008L0052 (дата звернення: 01.10.2020).

3. Середа О.Г. Медіація (посередництво) як альтернативний спосіб вирішення трудового спору. Право та інновації. 2017. № 2. С. 38-45.

4. Polskie Centrum Mediacji. O mediacji. URL: http://mediator.org.pl/o_mediacji/2/ (дата звернення: 28.09.2020).

5. Gerasimova Zoi a; Georgiev Stanislav. Mediacii ata - alternativen sposob za razreshavane na sporove. $T$ rgovsko i konkurentno pravo. 2007. № 2. C. 25-32.

6. Collective Dispute Resolution through Conciliation, Meditation and Arbitration : European and ILO Perspectives. Geneva, 2007. P. 25.

7. Кармаза 0.0. Інститут медіації: основні концепції розвитку. URL: http://pgp-journal.kiev.ua/ archive/2017/2/6.pdf (дата звернення: 30.09.2020).

8. Кривенко Д.Є. Ознаки медіації як способу вирішення трудових спорів. Актуальні проблеми права: теорія і практика. 2020. № 1 (39). С. 143-153.

9. Стратюк А.О. Особливості медіації у вирішенні трудових спорів. Соиіальне право. 2019. № 1. C. $157-162$.

10. Григор 0.0. Поняття консенсусу в сучасній вітчизняній філософсько-політичній думці. Науковий часопис Національного педагогічного університету імені М.П. Драгоманова. 2019. Вип. 25. C. 9-16.

11. Парламент схвалив законопроект про медіацію. URL: https://sud.ua/ru/news/laws/ 173792-parlament-skhvaliv-zakonoproekt-pro-mediatsiyu (дата звернення: 20.09.2020).

\section{Анотація}

Шумна Л. П., Сікун А. М., Кисельов Д. В. Інститут медіації як альтернативний спосіб вирішення трудового спору. - Стаття.

У статті досліджено поняття медіації, перспективи розвитку цього інституту як альтернативного способу вирішення трудових спорів у сучасних умовах українського законодавства. Розглянуто історичний шлях виникнення медіації, її подальший розвиток у закордонних країнах. Розкрито дефініції поняття медіації, які поданні науковцями та зазначенні в інших нормативних актах нашої держави і держав зарубіжжя. Проведено аналіз доцільності вирішення трудових спорів за допомогою процедури медіації як нового альтернативного методу вирішення індивідуальних та колективних трудових спорів, окреслено її переваги й ефективність, розглянуто моделі інституцій, які мають право здійснювати процедуру медіації в іноземних країнах, їхні підстави функціонування в цих державах. Досліджено порядок вибору інституції, яка здійснює медіацію, та порядок підбору і призначення особи, яка має право проводити процедуру медіації в закордонних країнах. Розглянуто, на яких засадах проводиться процедура медіації в нашій державі, школи, створені громадськими об'єднаннями, які готують фахівців для проведення процедури посередництва та примирення (медіація).

У процесі проведеного дослідження розглянуто погляди вчених, які досліджують медіацію як альтернативний метод урегулювання спорів. Опрацьовано та досліджено нормативне та правове регулювання, функціонування зазначеного способу в іноземних країнах, досліджено нормативні акти, у яких уже закладено підгрунтя для функціонування інституту медіації в нашій країні. Розглянуто терміни та строки проведення процедури примирення в закордонних країнах. Наведено чинники дієвості інституту посередництва під час вирішення трудових спорів, доцільності запровадження медіації в нашій державі й ухвалення нормативного акта у вигляді закону, який не тільки б узаконив функціонування інституту медіації в різних сферах, а і забезпечив правове регулювання всім учасникам цього процесу, практика застосування якого була б на рівні судової.

Ключові слова: медіація, посередництво, трудові спори, індивідуальний спір (конфлікт), колективний спір, примирення. 


\section{Summary}

Shumna L.P., Sikun A.M., Kyselov D. V. The institute of mediation as an alternative way of resolving a labor dispute. - Article.

This article examines the concept of mediation and the prospects for the development of this institution as an alternative way of resolving labor disputes in modern domestic Ukrainian law. The historical way of origin of mediation and its further development in foreign countries is considered. Definitions of definitions of the concept of mediation which are presented by scientists and specified in other regulations, both our state and the states of abroad are revealed. The expediency of resolving labor disputes through mediation as a new alternative method of resolving individual and collective labor disputes is analyzed, its advantages and effectiveness are outlined, models of institutions that have the right to conduct mediation in foreign countries and their grounds in these countries are considered. The procedure for selecting an institution that carries out mediation and the procedure for selecting and appointing a person who has the right to conduct and conduct a mediation procedure in foreign countries have been studied. It is considered on what basis the mediation procedure is carried out in our state, and schools established by public associations that train persons who conduct the mediation and conciliation procedure.

The study examines the views of scholars and scholars involved in the study of mediation as an alternative method of dispute resolution. The normative and legal regulation and functioning of this method in foreign countries have been worked out and researched, and the normative acts in which the foundation has already been laid for the functioning of the mediation institution in our country have been studied. The terms and terms of the conciliation procedure in foreign countries are considered. The factors, the effectiveness of the institution of mediation in resolving labor disputes, the feasibility of mediation in our country and the adoption of a normative act in the form of a law that would not only legitimize the functioning of the institution of mediation in various fields, but also provide legal regulation to all participants. which would be at the judicial level.

Key words: mediation, entrepreneurship, labor disputes, individual dispute (conflict), collective dispute, comparison. 